\title{
Are We Still Illyrians?
}

\section{Valerie Higgins}

The American University of Rome

\begin{abstract}
This paper examines the changing attitudes of young Albanian archaeologists to Albania's archaeological heritage. As Cold War archaeologists retire and are replaced by a generation trained after the fall of communism, this paper asks how their different world perspective will influence the future direction of archaeology. Particular issues that are addressed are the perceived role of the Illyrians in national identity and the willingness of young archaeologists to embrace new types of heritage sites, such as industrial and Cold War archaeology. Examples of the latter are very prominent in the Albanian landscape, but their interpretation and incorporation into the national narrative are still contentious issues for many.
\end{abstract}

Keywords: Albania, Butrint, cultural heritage, Illyrians, Cold War.

\section{Introduction}

The history of Albanian archaeology could be summarized as brief but intense. Until 1912 the area was part of the Ottoman Empire, but even after it became officially independent, Albania was still unstable and subject to foreign influence. This was particularly so after 1928 when the country came under the influence of Fascist Italy. This meant that until the Second World War archaeological excavations were largely controlled by Italian and other foreign teams (see Cella et al. 2016). These projects were often more interested in the area as part of Greek and Roman history, rather than exploring it for its own historical development.

With the victory of communism in the post-war period, Albania finally became a fully autonomous country but, at the same time, a country in lockdown, almost entirely cut off from the outside world. A strong Stalinist ideology not only sought to control every aspect of its inhabitants' lives, but also ensured that their contact with other nationalities was minimal. Albanians were not free to travel and the small number permitted to leave the country usually only travelled as far as other approved communist states. Foreigners were allowed to visit only for very brief periods. The country was on a perpetual war footing against attack from the menacing outside world. This state of readiness required the building of huge fortifications and hundreds of thousands of bunkers, whose imposing physicality ensured a heightened tension, especially in border areas (Fig. 1).

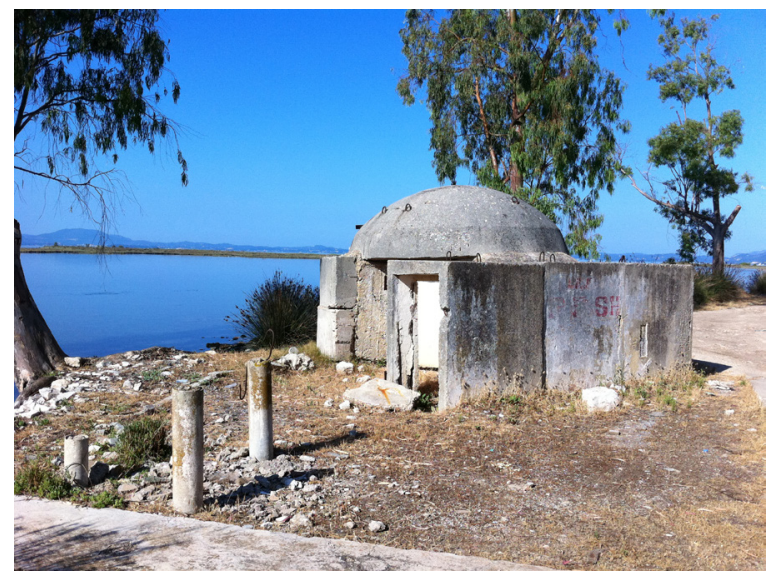

Figure 1. A communist era bunker on the Vivari Channel near Butrint (photograph by V. Higgins). 
In 1948, the Albanian leader, Enver Hoxha, began the forerunner of what would develop into the Albanian Institute of Archaeology: museums and high profile conferences followed and in 1971, a new journal called Illiria commenced publication (Hodges 2000: 3). Under Hoxha, the focus of state-sponsored archaeology increasingly emphasized the identity of Albanians as an autochthonous group with unbroken descent from the Illyrians, an ancient tribal grouping mentioned in classical texts. The idea of a distinct ethnic origin, native to the land within the borders of modern-day Albania, was crucial to the government's propaganda. Excavations obligingly provided evidence of long continuous habitation sequences, to back up the claim that the population was totally indigenous, without outside influences (Gilkes 2013: 15). The contrast with the approach of preSecond World War foreign teams could not have been more stark.

The most immediate impact on archaeology of the fall of communism and establishment of a democratic government was not so much ideological but financial. Funds for excavations, personnel, publications and museums dried up. The archaeological establishment for the most part continued, albeit with reduced resources, and as it was heavily invested in the Illyrian national narrative, there was no immediate broadening of intellectual approach. The opening of the borders enabled foreign expeditions to return to Albania, but the political instability of the 1990s was a deterrent for all but a few teams. Thus, entering the twenty-first century, Albanian archaeology was still largely locked into a Cold War model, a decade after it had ceased to have any political utility. The fall of communism had other consequences for the cultural heritage record. The Cold War monuments themselves became obsolete. They are the tangible witnesses to a remarkable half century of history. In addition to the aforementioned military installations, there is also an impressive array of redundant industrial plants. In other parts of the western world the transformation into an industrialized form of manufacturing was a process that took the best part of century. In Albania it was achieved practically overnight, but the factories, once built, were rarely updated. By the time of the fall of communism they had long ceased to be cost effective and only continued to function because of heavy state subsidy. Today many of them are now abandoned and they are outside the framework of the official state heritage services (Fig. 2).

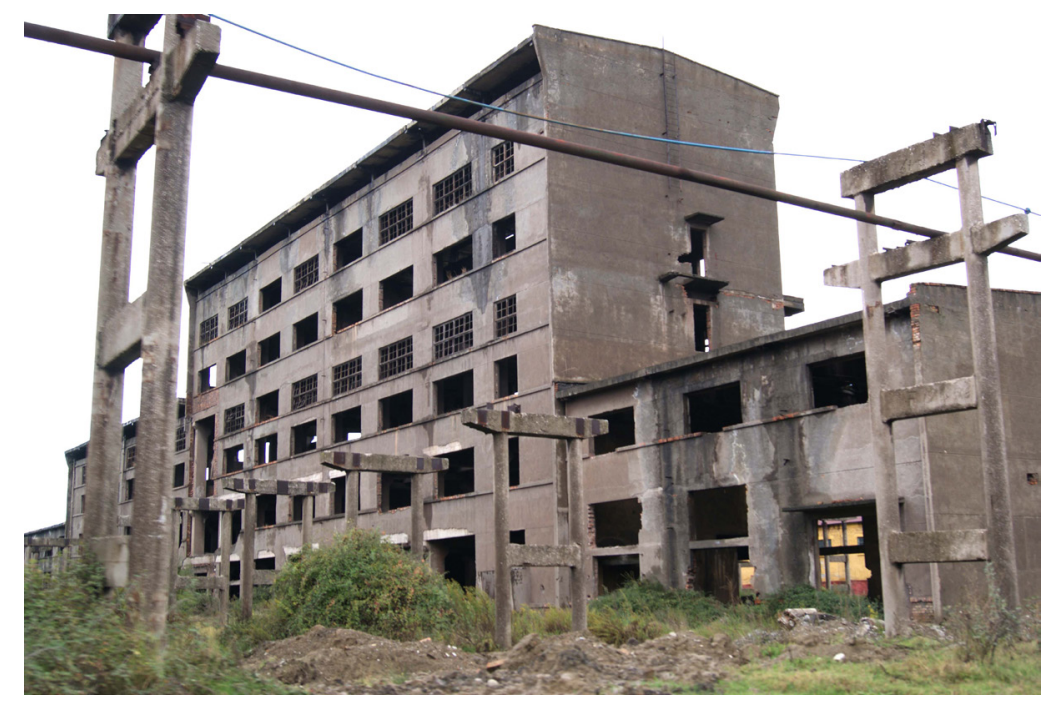

Figure 2. 'Steel of the Party' Metallurgical Combine at Elbasan (photograph by I. Parangoni). 
The objective of the research presented here was to try to understand the perceptions, aims and aspirations of the young archaeologists who are just beginning their career: to determine how far this new generation sees Albanian archaeology in terms of the old communist Illyrian model, and to understand their views on other aspects of cultural heritage, such as industrial and Cold War heritage.

\section{The Survey}

The research presented here was conducted between 2010 and 2012 using a group of young Albanians who were taking part in the Butrint Field School in southern Albania (Fig. 3). The participants were mostly from the University of Tirana but some expatriot Albanians from Kosovo and Macedonia were also included. The field school was subsidized by the Butrint Foundation, and competition amongst students to participate was fierce. The sample included a small group of slightly older participants acting as supervisors. These were former students of the field school who had moved on to have jobs in archaeology or to study for a postgraduate degree. Thus, the group, although small in number, represents the most committed and best placed candidates to pursue a career in archaeology, the ones who are most likely to be running Albanian archaeology in future years.

The data were collected by means of a written questionnaire followed by a semi-structured interview. As I was working and living with the group, participant observation also informed some aspects of the research. The majority of the respondents spoke English well enough to conduct the interviews without assistance. Seven interviewees asked a friend to come with them, but for the most part did not call on their services. A total of 35 participants were interviewed

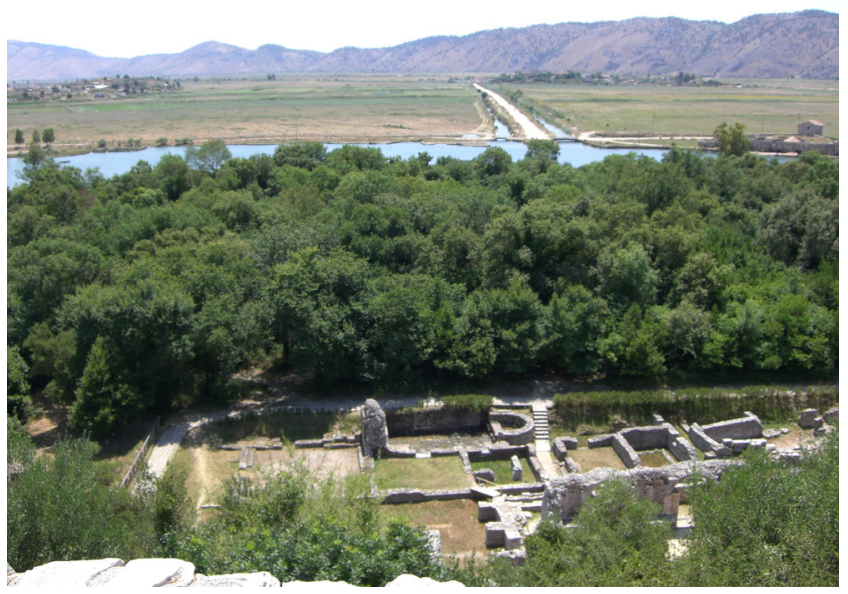

Figure 3. The Roman remains at Butrint (photograph by V. Higgins). comprising 25 students and ten supervisors. The results showed no great difference between the two groups with the exception of one question, which I will elaborate upon below. The group was evenly divided as regards gender (18 females, 17 males) and there were no marked gender differences in the responses.

\section{Importance of different periods of history}

In an attempt to understand the participants' feelings about the importance of different periods of archaeology in Albania the following question was posed "What do you think is the most important period of history?"

There was no consensus in the answers to this question: 12 out of 35 thought all periods were equally important. This, of course, is the message taught by contemporary 
archaeological theory and one cannot discount the possibility that they gave the answer they thought was expected of them.

Six perceived medieval archaeology as the most important. If we include in this group also the three who stated Skanderbeg (a fifteenth century warrior who fought the Turks) we get nine in total who saw the period before Ottoman domination as crucial. This is certainly the period that appeals most to the popular version of Albanian identity, as I witnessed personally when I stayed in a hotel in Tirana, where the former communist building had been given a somewhat incongruous make-over as a medieval castle. The growth of tourist resorts such as Kruje bear witness to the popularity of this image (Figs. 4 to 7). Here the restored and reconstructed buildings of the castle and the reproduced fittings inside give an evocative picture of a proud (and highly photogenic) warrior nation.

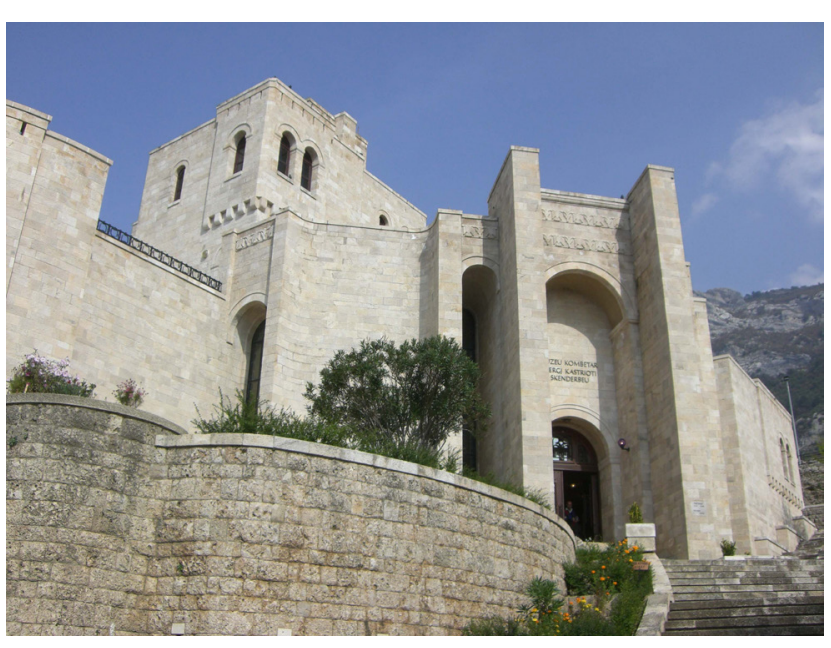

Figure 4. The reconstructed castle at Kruje housing the Skanderbeg Museum (photograph by V. Higgins).
Less predictably, an equal number, nine in total, saw the Cold War and post Cold War period as the most important in the development of Albania. This was the one area where there was a small divergence between the views of the students and the slightly older group of supervisors. Even if they did not necessarily perceive it as the most important period, all of the supervisors thought it essential to include more recent material in the archaeological record and, during the inter-

view, some of them expressed strong opinions on this. Some of the supervisors had vague memories of communism from their infancy, which mostly related to festivals and parades, which they had enjoyed. They were sufficiently close to the events of that period to have been touched by them. I did not pick up this sentiment in the interviews with the students, who were all born after the fall of communism. During the interview participants were asked "Should heritage sites preserve the material culture of modern periods such as the Second World War and Communism?" Overall 28 out of 35 replied yes, but significantly, this included everyone in the older group, and several elaborated upon this at some length.

In formulating the questionnaire and interview questions a conscious decision was made to avoid the word 'Illyrian', to allow the participants to employ it in their own way without prompting. The respondents mentioned it very little. Only one student actively employed the Illyrian archaeological model: s/he felt that prehistory was the most important period of archaeology because through prehistory it would be possible to demonstrate autochthony, which s/he regarded as crucial to Albanian identity. 


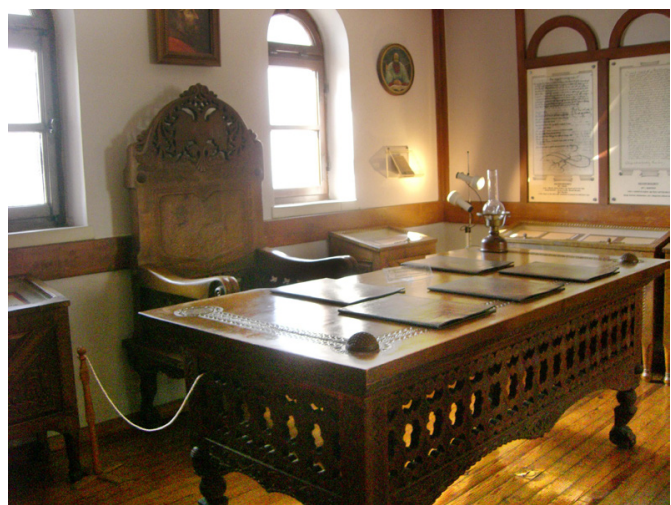

Figure 5. The reconstructed study of Skanderbeg showing him as an intellectual but also larger than life as the furniture is over-sized. There is little historical evidence for either of these interpretations (photograph by V. Higgins).

\section{Reasons for Studying Archaeology}

The participants were asked why they had decided to study archaeology: 31 of the 35 stated personal interest as the main reason for studying archaeology. The remaining four had chosen it for practical reasons, such scholarship opportunities or lack of space on their course of first choice. All of those who chose to study it for personal interest wanted to carry on with a career in archaeology, conservation or heritage. Upon interview most of them equated archaeology with an opportunity to travel, and this may relate to the specific circumstances of this site because the Butrint Foundation has afforded opportunities for young Albanian archaeologists to study abroad (Hodges 2000: 4). A strong desire to travel, and even work, abroad was common to all participants. Of the four who did not envisage carrying on in archaeology, two wanted to go into tourism, one into journalism and one did not have any plans as yet. The students who had ambitions to work in tourism saw archaeology as a potential route into tour guiding, which would give them an entrée into the tourist industry.

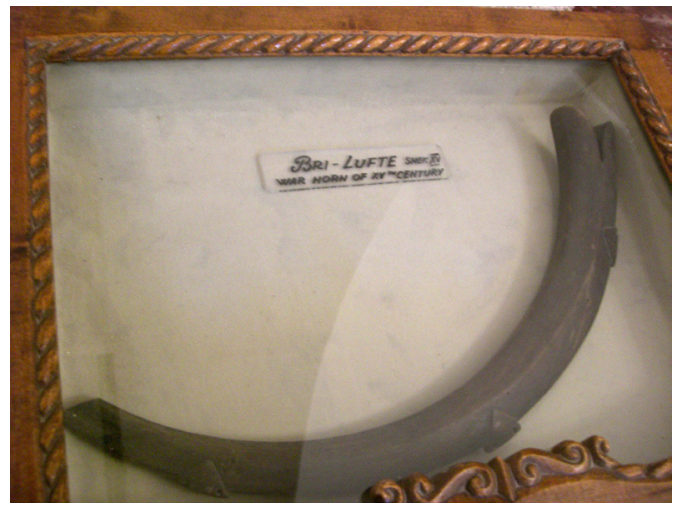

Figure 6. Exhibit of war horn from the Skanderbeg Museum (photograph by V. Higgins).

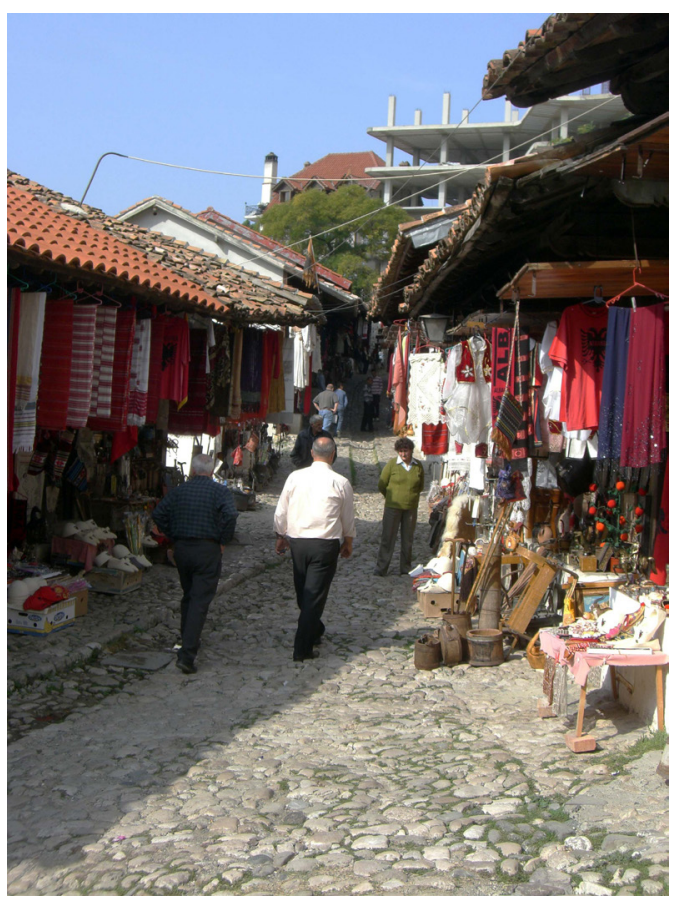

Figure 7. Market outside the Skanderbeg Museum selling souvenirs to tourists (photograph by V. Higgins). 


\section{The Role of Archaeology in Albania's Future}

Participants were asked "What can archaeology contribute to Albania's future?" and they were permitted to include as many variables as they wanted. The answers could be classified as covering three areas:

1. Important for identity within the country $-21(60 \%)$

2. To develop the economy and promote tourism - 15 (43\%)

3. To enhance the status of Albania abroad - $9(26 \%)$

Thus the role of archaeology as providing an Albanian identity is still perceived as very important, but clearly not in the mould of the communist Illyrian model. The concept of Albanian identity was sometimes linked in their answers to the third factor, enhancing the status of Albania abroad. Many young people, even those who have never left Albania, are acutely aware of the negative image of their country that is often portrayed to the outside world. The respondents felt proud of the fact that Albania had a long and glorious history as part of the Greek sphere of influence and a colony in the Roman Empire. Interestingly, even though official rhetoric was directed towards an autochthonous model, during the communist period there was, at the same time, a paradoxical pride in the classical past of Albania. Hodges (2009) has recorded how Hoxha took the Soviet leader Krushchev to visit Butrint. Hoxha was disgusted when Krushchev perceived no value in its glorious ruins and saw only a highly suitable spot for a submarine base.

At the time this survey was taking place, Albania was pressing to be made a full member of the European Union and in 2010 they achieved status as a Schengen country which made foreign travel much easier. Albania's 'European' history was much promoted by the government during this period (see Phelps 2016). Herzfeld has recorded a similar phenomenon at Rethemnos in Crete. In a period when Greece was seeking entry to the European Union, the conservation of European heritage was systematically privileged and Ottoman heritage was allowed to decay or be changed (Herzfeld 1991: 57-63 and photos 24 and 25, 121). Though it should be noted that, in Albania, Ottoman heritage has not been unduly neglected (Fig. 12).

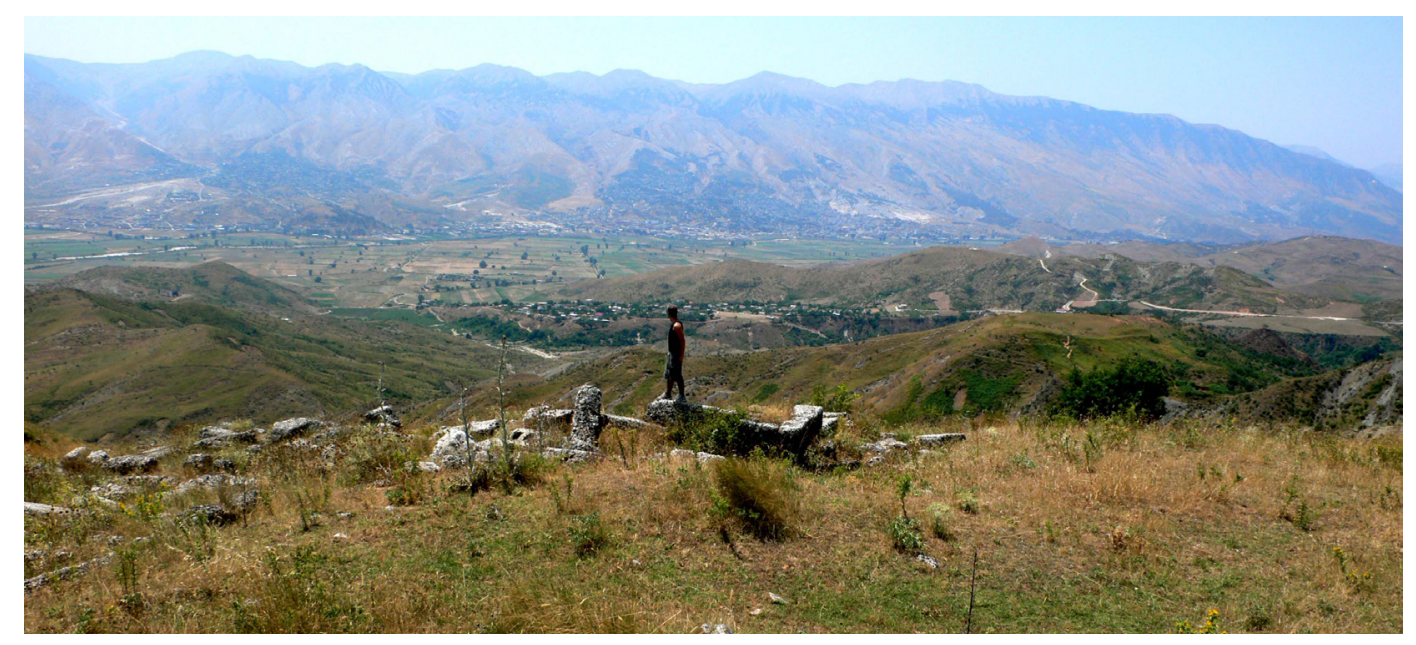

Figure 8 . The $3^{\text {rd }}$ Century BC site of Antigoneia (photograph by V. Higgins). 
The development of heritage tourism was seen by 15 of the respondents as a way in which archaeology could help the economic development of Albania. Similar views were expressed to me by local traders. There is, for sure, no lack of raw material. As well as three UNESCO World Heritage Sites, there is a wealth of smaller sites set in impressive scenery (Fig. 8). Albania also has spectacular beaches, some of which are well developed, especially those further north that are more easily reached from Tirana. In 2014 the New York Times ranked Albania as fourth in its list of 52 places to visit "before the crowds" (NY Times 5 Sept 2014). The Lonely Planet guide listed Albania as one of its top countries to visit in 2011 and predicted "Albania won't be off the beaten track for much longer" (Lonely Planet 2011).

However, despite the confidence in Albania's potential as a tourist destination, international tourism in Albania has failed to take off. In fact, the 2015 Annual Research data produced for the World Travel and Tourism Council (WTTC 2015: 1) showed a decline in both the direct contribution and total contribution of travel and tourism to the GDP. Direct employment in travel and tourism remained static but total employment has declined (WTTC 2015: 9). The outlook for long-term growth was only slightly more optimistic (WTTC 2015: 10). So what went wrong?

Recent studies of the cultural tourism industry in Sicily have revealed that no matter how beautiful the scenery or wonderful the heritage, in the absence of supporting development, these factors will not lead to economic benefits or a growth in tourist numbers:

"our results show that cultural endowment can be not sufficient to attract tourism demand, in the absence of adequate accommodation supply and infrastructure in general" (Cuccia \& Cellini 2007: 269).

The constant building activity in Albania, especially around the coast near Butrint, gives the superficial impression of great progress in infrastructure, but this is an illusion. It is not yet sufficiently co-ordinated or linked into tourist networks to have much of an impact (Fig. 9). Travel industry professionals cite the negative image of Albania as a corrupt and potentially dangerous country as a reason for lack of interest in Albania as a holiday destination. The unreliability of basic services such as efficient sewage, paved roads and pavements etc. is a less dramatic, but possibly equally as important, factor. Many of the major tour operators do not include Albania in their offerings. The foreign visitors who make extended stays in Albania are, for the most part, from neighbouring Kosovo, Montenegro and Macedonia (Ochsenbein 2013). 


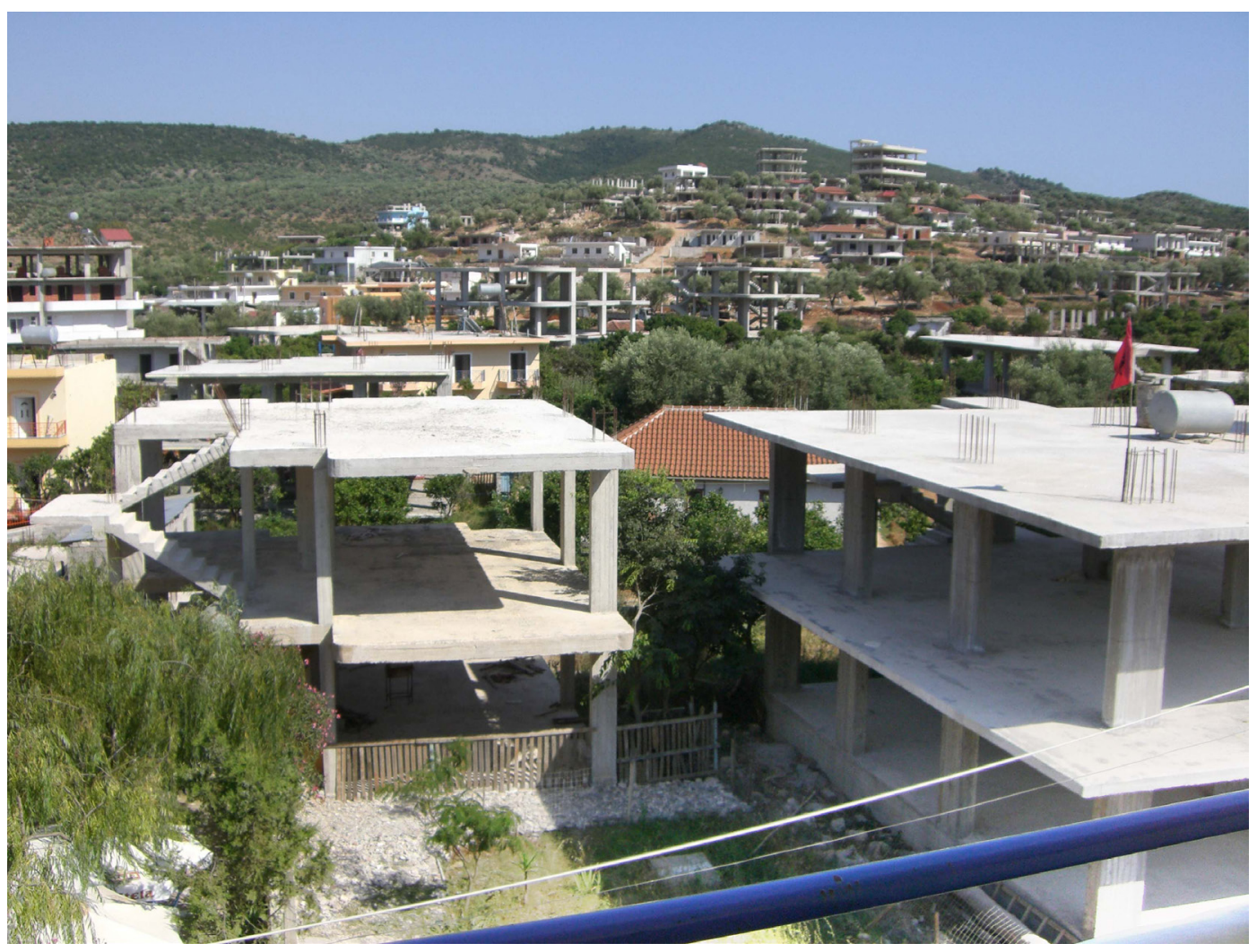

Figure 9. The seaside resort of Ksmele. This is typical of the unplanned building activity often seen along this coast (photograph by V. Higgins).

It is not always the absence of visitors that is the problem so much as the type of visit. Butrint itself attracts many foreign tourists, but a large proportion of them come as a day trippers from Corfu and spend very little time, and almost no money, in Albania. Personal observation of the tours revealed that they drive from the ferry straight through the local towns and only stop at a small number of particular restaurants with whom the tour operators have an agreement. The groups witnessed on the ferry from Corfu to the local port of Sarandë even had their water supplied to them from Greece. In Albania they left only the empty bottles. Groups from cruise ships also visit the site of Butrint, but like the day trippers from Corfu, spend little time and even less money on Albanian soil (Ochsenbein 2013). This type of tourism does not benefit the local population and may even be harmful as it is local authorities who have to manage the problems of traffic, large buses on narrow roads, parking and collecting the garbage. The older group of survey participants was acutely aware of the problems with the type of tourist attracted to Butrint. On several occasions they pointed out to me examples of day trippers being dissuaded from purchasing anything on the site. I also heard the guides of English speaking groups telling tourists that they should not buy anything in Albania. 
The desire expressed by some survey participants of portraying Albania as a country with a long and glorious history may, at first sight, seem esoteric and impractical. Yet seen from a different perspective, it could be an extraordinarily perspicacious insight into one of the biggest difficulties facing the development of heritage tourism. Albania still has an image as a backward country, cut off from the rest of the world, even slightly dangerous (this seemed to be the implication of the warnings to foreign tourists not to purchase anything). This image impedes the development of its heritage tourist industry. Helping to change that image may yet prove to be one of the most useful roles that archaeology can play in promoting the future economic prosperity of Albania.

\section{Conclusions}

This survey makes no claims to be comprehensive. It is a snap shot of the views of young archaeologists at a particular moment in Albania's history, a moment of great change as the generation of Cold War archaeologists retires. However, it provides some important insights into how regime change trickles down into societal change and some clues as to how it might develop in the future.

Public support of archaeology is disappearing. More than once I heard established older archaeologists lament that under communism they had never wanted for funds but now they could do very little. The withdrawal of state aid is something Albania has in common with the rest of Europe, but its impact is very different. In western Europe the shift away from public funds tends to result in long and often bitterly fought internecine struggles as the official structure morphs into its new form. However, essentially there remains an establishment structure, which runs the nation's heritage. One thinks, for example of the transformation of the Royal Commission of Historic Monuments into English Heritage in 1999. In Albania one sees instead the gradual winding down of the state structure, whilst at the same time, a parallel non-state sector is developing and moving into the spaces vacated. The latter are able to take advantage of the expertise and funding available through foreign foundations and NGOs. These entities are more flexible and are better suited to dealing with some of the new issues mentioned above and can be more locally adaptive.

The Cold War heritage is finally being recognized as a remarkable resource. The most impressive example is the vast tunnel complex under the castle at Gjirokastra (Fig. 10). At points it is $85 \mathrm{~m}$ deep and it has over a hundred rooms. It was designed to house local officials in case of nuclear attack (Fig. 11). The tunnel is being turned into a Cold War museum for the display of items used during the communist period and it is also planned to incorporate an experiential element that will allow visitors to understand the emotions of fear and anxiety that characterized the period. The project aims to link up different parts of the city, such as the castle with the bazaar, and thereby promote a heritage trail (Nepravishta 2014: 278-281). 


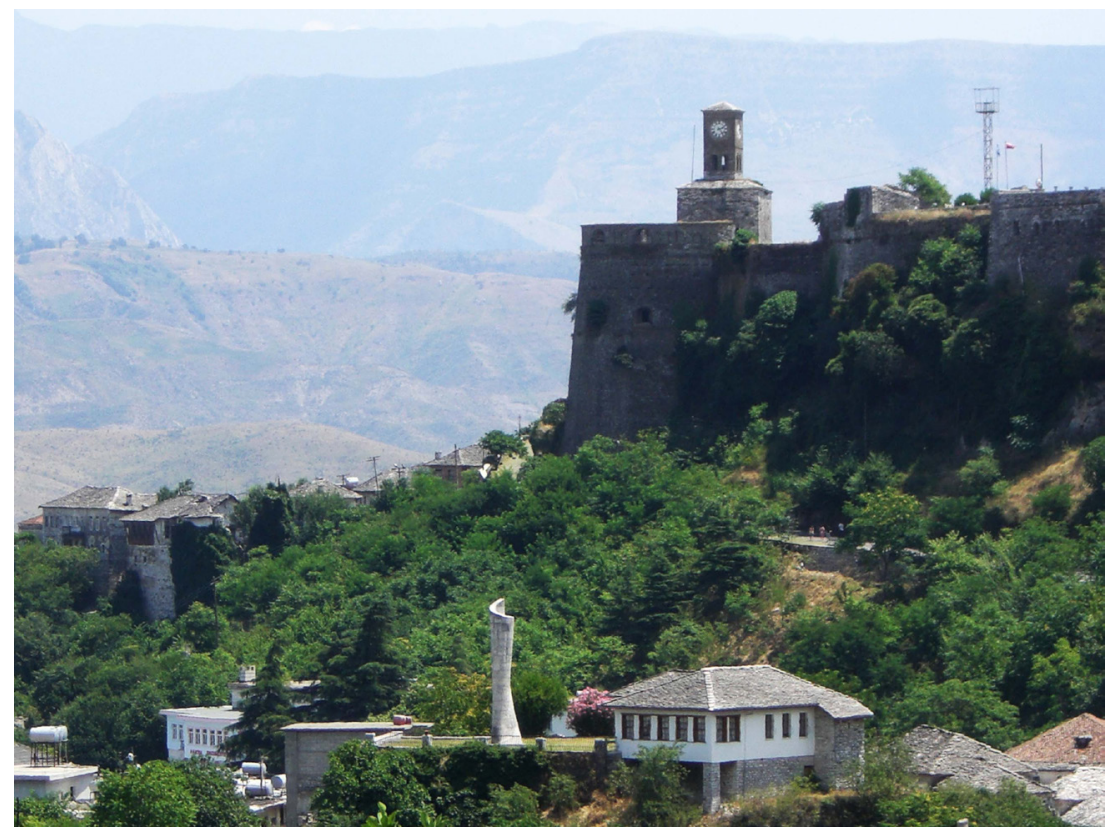

Figure 10. Gjirokastra Castle (photograph by V. Higgins).

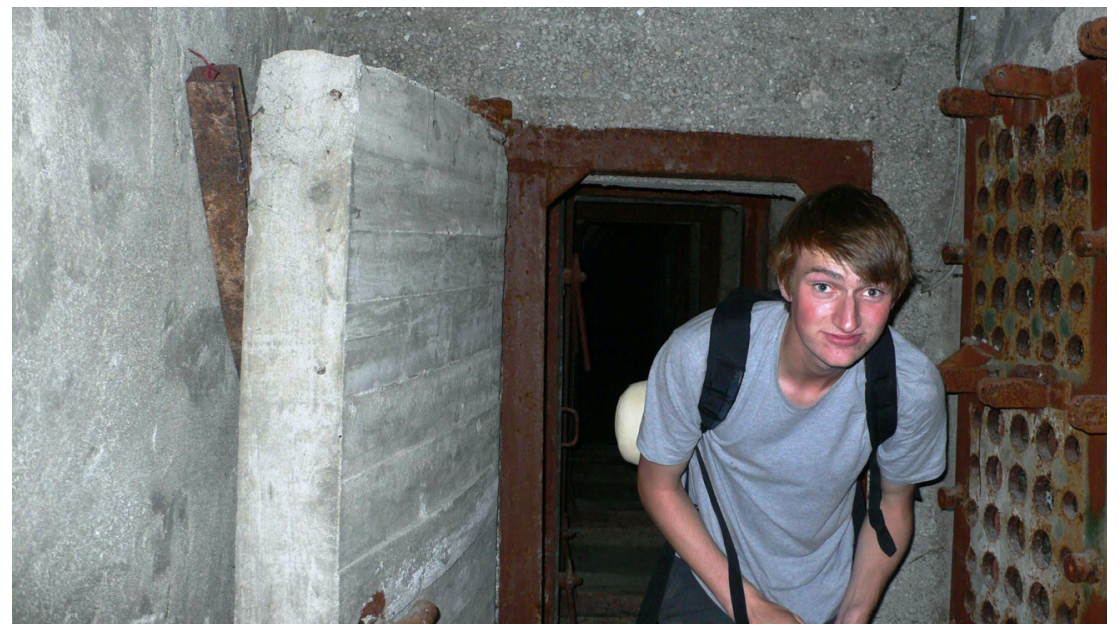

Figure 11. The tunnels under Gjirokastra castle (photograph by O. Gillkes).

The submarine tunnel at Porto Palermo is another candidate for a Cold War museum. The advantage of this site is that it is situated in a beautiful coastal bay with a picturesque Ottoman castle on the headland. Therefore, it is already well placed for attracting tourists and the museum would have a ready audience (Nepravishta 2014: 276). More recently, a large bunker near Tirana, built for the personal use of Enver Hoxha, has been turned into a tourist attraction and exhibition centre with the approval of Albanian Prime Minister, Edi Rama (BBC 22 Nov 2014): see also Iacono \& Këlliçi (2016) on attitudes to Enver Hoxha's pyramid in Tirana.

There is also a movement to help preserve the industrial archaeology of Albania which has formed under the initiative of one of the supervisors in this survey (Ilir Paran- 
goni). Although still in its early stages, its projects include constructing models for an exhibition for schools, delivering lectures in universities, launching a journal and publishing a book (Parangoni 2015; Trakult Centre Newsletter 1 2014; Trakult Centre Newsletter 6 2015). Specialised tour companies such as 'Albanian Tour' now include industrial archaeology in their offerings and employ young Albanian archaeologists as tour guides.

These initiatives hold out promise for the future and the survey results indicate the upcoming generation of archaeology graduates would embrace these new opportunities. It is clear that much can be achieved with a combination of private public partnerships, particularly on a local level.

However, it is also apparent that, in the absence of infrastructure investment, these

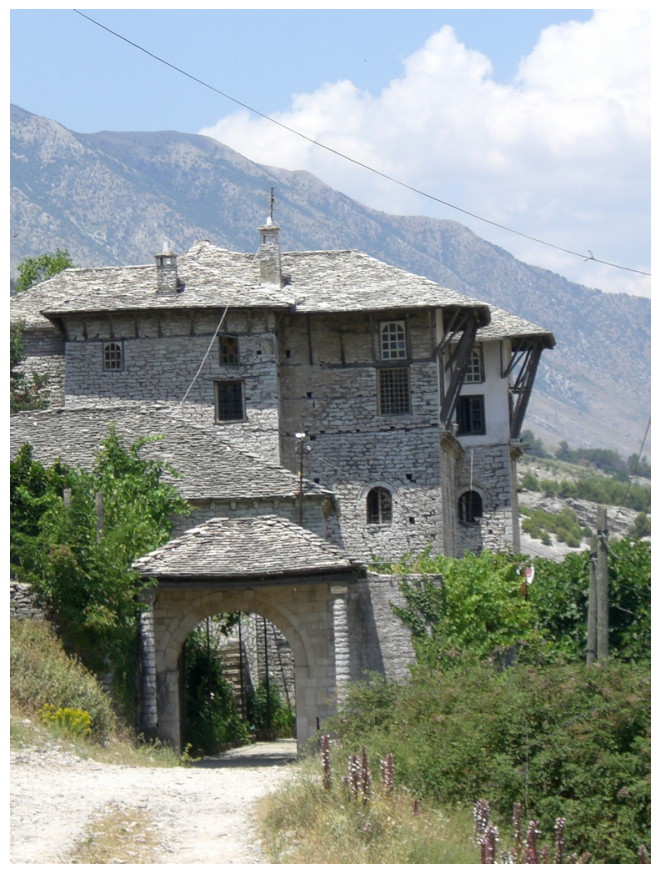

Figure 12. Ottoman house at Gjirokastra (photograph by V. Higgins). kinds of initiatives can only achieve a limited success. Whilst public organizations are not necessarily needed to manage a heritage site, conserve antiquities or set up a museum, they are crucial for building roads, putting in water and sewage systems and ensuring a reliable electricity supply. The biggest challenge facing the next generation of archaeologists may not be the lack of public money for heritage, so much as the lack of public money for everything else.

\section{References}

Cella, E., M. Gori \& A. Pintucci, 2016. Archaeology in the Adriatic. From the dawn to the sunset of communist ideologies, in: M. Gori \& V. Higgins (eds.), The Impact of the Fall of Communism on European Heritage. Proceedings of the 20th EAA conference held in Istanbul 10-14 September 2014. Ex Novo Journal of Archaeology 1: 15-24.

CuCCIA, T. \& R. CELLini, 2007. Is cultural heritage really important for tourists? A contingent rating study. Applied Economics 39: 261-271.

Gilkes, O., 2013. Albania: An Archaeological Guide. London, New York: I.B.Taurus. Herzfeld, M., 1991. A Place in History: Social and Monumental Time in a Cretan Town. Princeton, New Jersey: Princeton University Press.

Hodges, R., 2000. Archaeology in Albania after Kosovo. History Today, March 2000: 3-4. Hodges, R. 2009. Nikita Khrushchev's visit to Butrint. Expedition 51.3: 24-26.

IACONO, F. \& K. KëLLIÇI, 2016. Exploring the public perception of communist heritage in Post-communist Albania, in: M. Gori \& V. HigGins (eds.), The Impact of the Fall of Communism on European Heritage. Proceedings of the 20th EA A conference held in Istanbul 10-14 September 2014. Ex Novo Journal of Archaeology 1: 55-69. 
Nepravishta, F., 2014. Regeneration of Brownfield military heritage in Albania, in: A. Dukić, D. Simonovic \& T. Vujičić (eds.), Browninfo: Towards a Methodological Framework for Brownfield Database Development. Banja Luka: University of Banja Luka, 271-286.

Ochsenbein, G., 2013. Tourism in Albania: a building site with potential. Accessed 26 May 2015. http://www.swissinfo.ch/eng/land-of-contrasts_tourism-in-albania--abuilding-site-with-potential/36008586.

Parangoni, I., 2015. Between Glory \& Fall: Albania \& the Industrial Experience. Tirana: Centre of Albanian Cultural Heritage, Trakult Centre.

Phelps, D., Heritage for development, multiethnic communities, and the case of Butrint National Park on the Albanian-Greek border, in: M. Gori \& V. HigGins (eds.), The Impact of the Fall of Communism on European Heritage. Proceedings of the 20th EAA conference held in Istanbul 10-14 September 2014. Ex Novo Journal of Archaeology 1: 5-11. Trakult Centre Newsletter 2014, No 1, Centre of Albanian Cultural Heritage, Trakult Centre, Tirana.

Trakult Centre Newsletter 2015, No 6, Centre of Albanian Cultural Heritage, Trakult Centre, Tirana.

World Travel and Tourism Council (WT'TC), Travel and Tourism Economic Impact 2015 Albania. London. Accessed 27 May 2015.

BBC “Albania opens huge Cold War bunker" 22 Nov 2014. Accessed 25 May 2015 http://www.bbc.com/news/world-europe-30160201

Lonely Planet's Top Countries for 2011. Accessed 27 May 2015.

http://www.lonelyplanet.com/travel-tips-and-articles/76164.

NY Times 5 Sept 2014. Accessed 25 May 2015 http://www.nytimes.com/interactive/2014/01/10/travel/2014-places-to-go.html “52 Places to Go in 2014”. 